\title{
Zastosowanie generatora plazmowego w zabiegach okuloplastycznych - doświadczenia własne
}

\author{
Plasma generator use in oculoplastic surgery: own experience
}

\section{Jaromir Wasyluk, Ilona Kaczmarek, Mariusz Strąk, Małgorzata Myślińska, Marta Dubisz}

Klinika Okulistyczna,

Wojskowy Instytut Medycyny Lotniczej w Warszawie p.o. Kierownika Kliniki: dr n. med. Jaromir Wasyluk

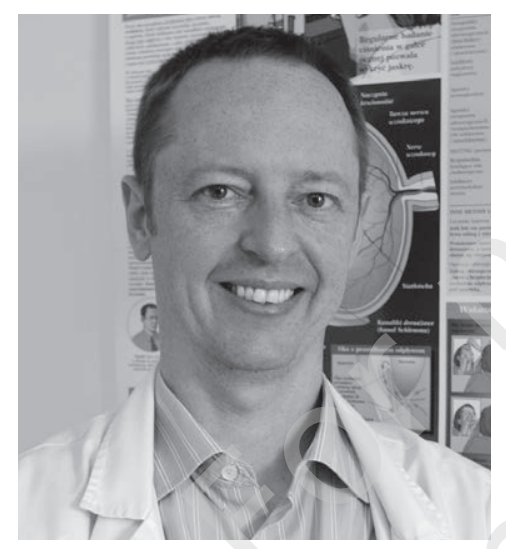

N A J W A Ż N I EJSZE Generator plazmowy jest obiecującym, nowym i mało inwazyjnym narzędziem chirurgicznym przydatnym w małych zabiegach okuloplastycznych.

\section{H I G H LI GHTS}

Plasma generator is a new, promising and mini-invasive surgical tool, useful in a minor oculoplastic lesions treatment.

\section{STRESZCZENIE}

W niniejszej pracy przedstawiamy przypadki kliniczne pacjentów ze zmianami skórnymi okolicy oczu operowanych w naszej klinice za pomocą nowatorskiego generatora plazmy (Jett Plasma Lift Medical ${ }^{\oplus}$, Compex spol. s r.o., Czechy). Jest to urządzenie zasilane prądem stałym, wytwarzające dzięki różnicy napięć przepływ energii elektrycznej w postaci zjonizowango powietrza (plazma) między końcówką sondy a tkanką i powodujące jej odparowanie. Pacjenci byli poddani zabiegowi w znieczuleniu miejscowym, a następnie przeprowadzono planowe kontrole z dokumentacją fotograficzną. Zabieg okuloplastyczny wykonany za pomocą generatora plazmy dobrze się sprawdził w usuwaniu drobnych zmian zlokalizowanych na skórze powiek, takich jak brodawczaki, włókniaki czy kępki żółte.

Słowa kluczowe: chirurgia okuloplastyczna, blefaroplastyka, zabiegi z użyciem plazmy, generator plazmy

\section{ABSTRACT}

In this paper we present a series of clinical cases of patients suffering from different cutaneous periocular lesions, treated in our depertment with the new plasma generator device (Jett Plasma Lift Medical ${ }^{\circledR}$, Compex spol. s r.o., Czech Republic). This direct current appliance induces air ionization (plasma) enabling electric current to flow between probe tip and the tissue, causing the last to evaporate. The subjects underwent this intervention in local anesthesia, followed by sequence of control visits with photographic documentation. This oculoplastic surgery showed good effectiveness in removing minor palpebral lesions, e.g., papilloma, xanthelasmae or fibromas.

Key words: oculoplastic surgery, blepharoplasty, plasma surgery, plasma generator 


\section{WSTĘP}

Generator plazmowy wykorzystany w niniejszej pracy (Jett Plasma Lift Medical ${ }^{\oplus}$, Compex spol. s r.o., Czechy) to niskoenergetyczne narzędzie elektrochirurgiczne zasilane prądem stałym, wytwarzające plazmowy łuk elektryczny [13]. Jest on szeroko wykorzystywany w chirurgii plastycznej i zabiegach medycyny estetycznej. Ostatnimi czasy jego popularność rośnie także wśród okulistów wykonujących procedury z zakresu drobnej chirurgii okuloplastycznej [1]. Zabiegi wykonywane tym narzędziem charakteryzują się niską inwazyjnością i szybką rekonwalescencją miejscową. Prezentowaną w niniejszej publikacji procedurę należy odróżnić od tej oferowanej przez obecne na rynku od dłuższego czasu urządzenia wykorzystujące technologię łuku elektrycznego (voltaic arc) czy noża plazmowego (plasma blade), które wywołują efekty cięcia przy jednoczesnej koagulacji otaczających tkanek $[1,2]$.

Zastosowanie generatora plazmowego jest szczególnie przydatne w miejscach wrażliwych, takich jak brzegi powiek czy skóra powiek, gdzie blizny powstałe w procesie gojenia po tradycyjnym zabiegu chirurgicznym mogłyby wpływać na widzenie lub komfort pacjenta. Skóra powiek jest tkanką wyjątkowo cienką, wrażliwą, a u osób starszych także bardzo wiotką, a więc wszelkie manipulacje chirurgiczne w tej okolicy powinny być szczególnie delikatne.

Technika działania generatora plazmowego polega na wytworzeniu krótkiego łuku elektrycznego na dystansie $2 \mathrm{~mm}$, za pomocą którego bezdotykowo uzyskuje się odparowanie tkanki, bez istotnego klinicznie efektu termokoagulacji, który zawsze ma komponentę uszkadzającą. Zjawisko to $\mathrm{w}$ literaturze opisuje się jako fulguracja prądem stałym. W przypadku prezentowanego urządzenia konstruktorom aparatu udało się ograniczyć działanie łuku plazmowego do powierzchni nawet $0,1 \mathrm{~mm}^{2}$, tym samym znacznie zwiększając precyzję zabiegu. Pomiędzy końcówką sondy a tkanką uzyskuje się różnicę napięć rzędu 5000 V, co prowadzi do przemiany otaczającego środowiska (w tym przypadku powietrza) $\mathrm{z}$ izolatora $\mathrm{w}$ przewodzącą prąd zjonizowaną plazmę.

Wskazaniami do zastosowania generatora plazmowego są następujące zmiany skórne: brodawczaki, brodawki łojotokowe, brodawki płaskie, angiokeratoma, teleangiektazje, włókniaki miękkie, rogowiaki kolczystokomórkowe, plamy soczewicowate, mięczak zakaźny, brodawki zwykłe, brodawki nitkowate, znamiona włośniczkowe, pajączki naczyniowe, rogowacenie słoneczne, rogowacenie starcze, rogowacenie łojotokowe, ostuda. Urządzenie najlepiej się nadaje do usuwania niewielkich płaskich zmian o grubości do $3 \mathrm{~mm}$, a także drobnych zmian mnogich na większych powierzchniach (np. kaszaki). Wykonując serie linijnie ułożonych impaktów na skórze, można też korygować nie- wielkiego stopnia zaburzenia ułożenia powiek (podwinięcie, odwinięcie, zwiotczenie). Prowadzone są także badania nad specjalną sondą, która może znaleźć zastosowanie w stymulacji powiekowych gruczołów Meiboma w leczeniu ich dysfunkcji.

Najważniejsze przeciwwskazania do zabiegu to: wszczepiony rozrusznik serca, implant ślimakowy czy inne wszczepione implanty zawierające układy elektroniczne, implanty metalowe wszczepione w pobliżu miejsca zabiegu, padaczka oraz ciąża.

Zabieg okuloplastyczny przeprowadza się w znieczuleniu miejscowym. Miejsce po usuniętej zmianie jest czyste i łatwo ulega epitelializacji, z przejściowym wytworzeniem strupa (odpada 7-10 dni po zabiegu). Należy pamiętać, że generator plazmowy nie zapewnia efektu cięcia, a więc nie jest możliwe wycinanie czy przecinanie żadnych struktur.

W naszej klinice przeprowadzono szereg zabiegów w różnych chorobach okulistycznych, takich jak: kępki żółte, brodawczaki, włókniaki, zmiany barwnikowe itp. z wykorzystaniem generatora plazmowego Jett Plasma ${ }^{\oplus}$. Poniżej przedstawiamy przykładowe przypadki chorych przed leczeniem, bezpośrednio po zabiegu oraz po 30 dniach od przeprowadzenia procedury.

\section{MATERIAŁ I METODY}

W Klinice Okulistycznej WIML w okresie od marca do kwietnia bieżącego roku przeprowadzono 15 zabiegów okuloplastycznych $\mathrm{w}$ różnych zmianach chorobowych okolicy oczu z wykorzystaniem generatora plazmowego Jett Plasma ${ }^{\circledR}$ (ryc. 1). Zabiegi te wykonywane były przede wszystkim ze wskazań estetycznych, ale także okulistycznych (rosnące łagodne zmiany typu włókniak czy brodawczak, zmiany skutkujące drażnieniem powierzchni oka).

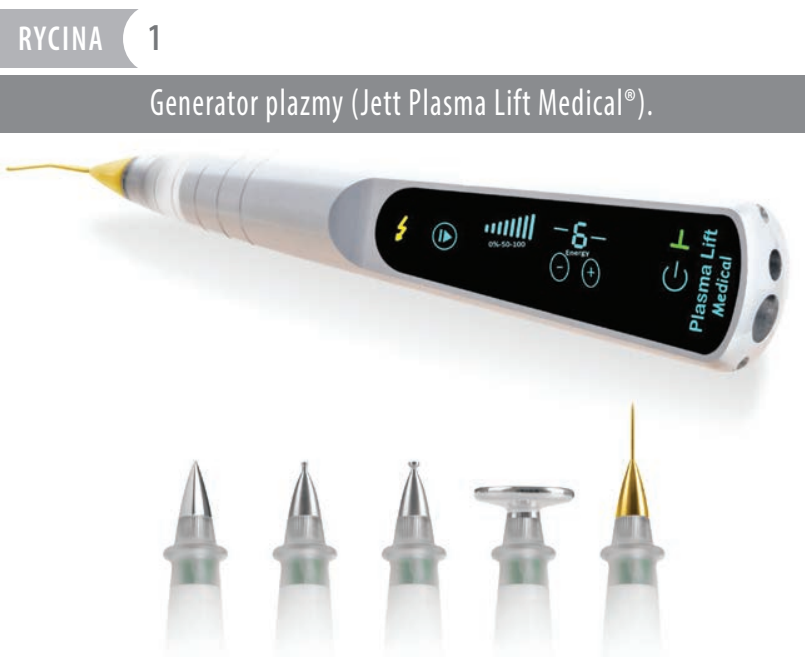


Procedurom zabiegowym poddano 11 pacjentów (6 kobiet, 5 mężczyzn). U 4 pacjentów wykonano jednocześnie zabieg obojga oczu. Średni wiek pacjentów zakwalifikowanych do badania wynosił 66,3 roku. Wskazania do zabiegu obejmowały: guzek brzegu powieki (4 pacjentów), brodawczaki skóry powiek (4 pacjentów), kępki żółte powiek (2 pacjentów), zwiotczenie skóry powiek górnych (1 pacjent). U każdej osoby wykonano 1 sesję terapeutyczną z zastosowaniem generatora plazmowego. Intensywność energii dostosowywano indywidualnie do charakteru i umiejscowienia zmiany, a jej zakres zawarty był w granicach 6.-8. poziomu mocy (jednostki niemianowane). U wszystkich pacjentów wykorzystano sondę dołączoną do zestawu, przeznaczoną do drobnych zmian skórnych.

Wszystkie zabiegi przeprowadzono w znieczuleniu miejscowym nasiękowym lignokainą. Po zabiegu stosowano na ranę maść z ofloksacyną (Floxal ${ }^{\bullet}$, Bausch Health, USA) 4 razy dziennie przez 7 dni. Kontrole stanu miejscowego prowadzono w schemacie: 7, 14, 30 dni po zabiegu. Efekt końcowy zabiegu oceniano badaniem w lampie szczelinowej oraz za pomocą dokumentacji fotograficznej.

\section{WYNIKI (ZDJECCIA)}

Po przeprowadzeniu jednej sesji zabiegów z użyciem generatora plazmowego Jett Plasma uzyskaliśmy satysfakcjonujący wynik u 9 z 11 pacjentów. W korekcji znacznego zwiotczenia skóry powiek górnych uzyskany efekt jednego zabiegu z wykorzystaniem plazmy był niewystarczający, co skłoniło nas do wykonania u tego pacjenta standardowej procedury chirurgicznej polegającej na wycięciu nadmiaru skóry. U jednego pacjenta poddanego zabiegowi z powodu kępek żółtych powiek obojga oczu efekt jednej sesji działania plazmy okazał się niewystarczający do usunięcia zmian, ale zdecydował się on na jej powtórzenie. Podczas wykonywania zabiegu część pacjentów odczuwała delikatnie pieczenie i ciepło. Zaczerwienienie i obrzęk tkanek będące skutkiem znieczulenia miejscowego oraz działania plazmy zwykle ustępowały po 2-3 dniach, w zależności od sprawności indywidualnych procesów naprawczych. Odpadnięcie strupa następowało po ok. 10 dniach od zabiegu. Poniżej przedstawiamy zdjęcia przykładowych pacjentów przed leczeniem, bezpośrednio po zabiegu oraz w 30. dobie od przeprowadzonej procedury (ryc. 2-6).
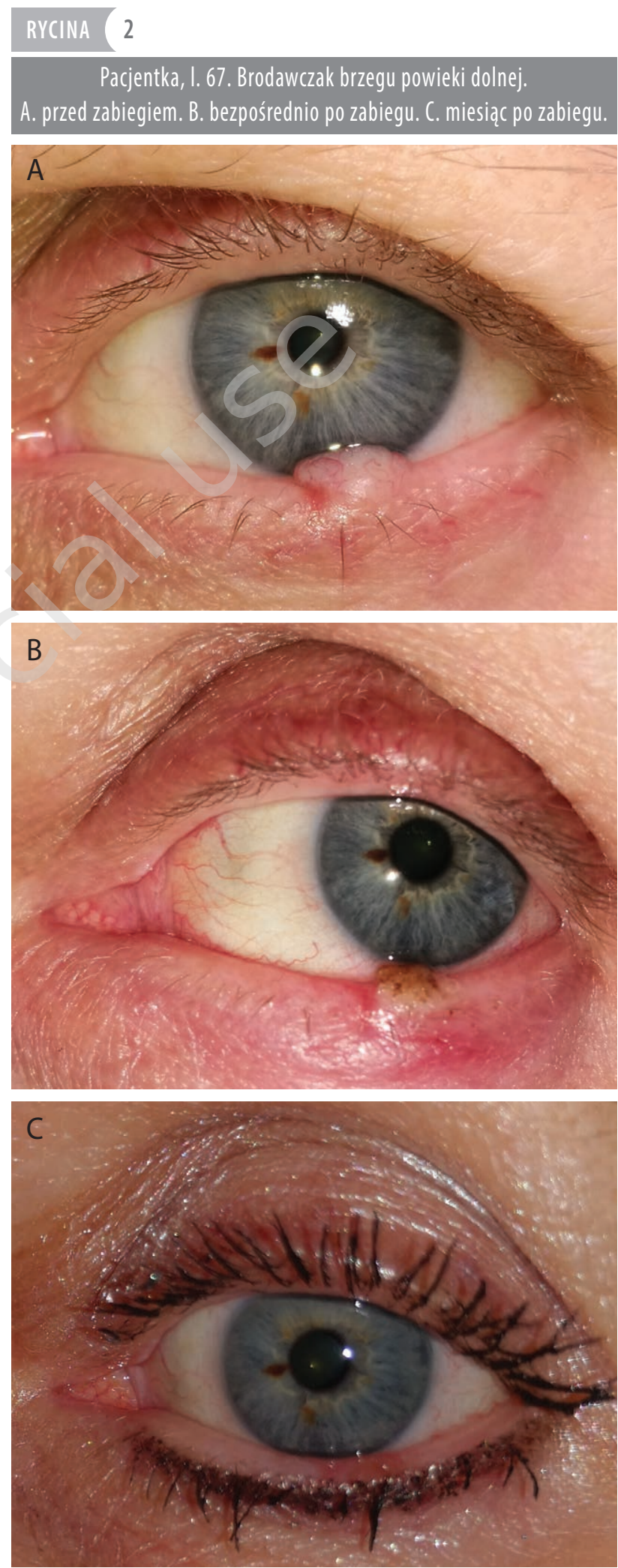


\section{RYCINA 3}

Pacjentka, I. 51. Brodawczak brzegu powieki górnej. A. przed zabiegiem. B. bezpośrednio po zabiegu. C. miesiąc po zabiegu.
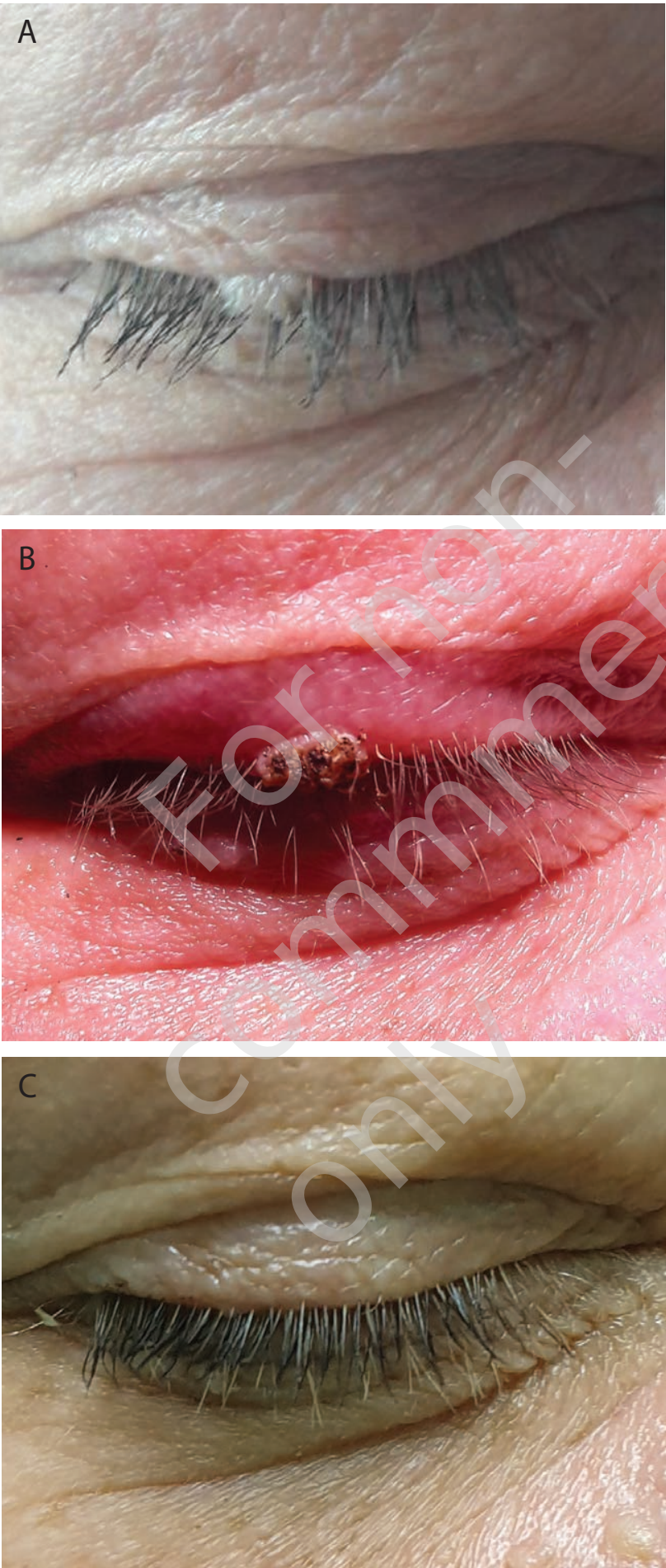

\section{RYCINA ( 4}

Pacjentka, I. 47. Kępka zólta powieki dolnej.

A. przed zabiegiem. B. bezpośrednio po zabiegu. C. miesiąc po zabiegu.
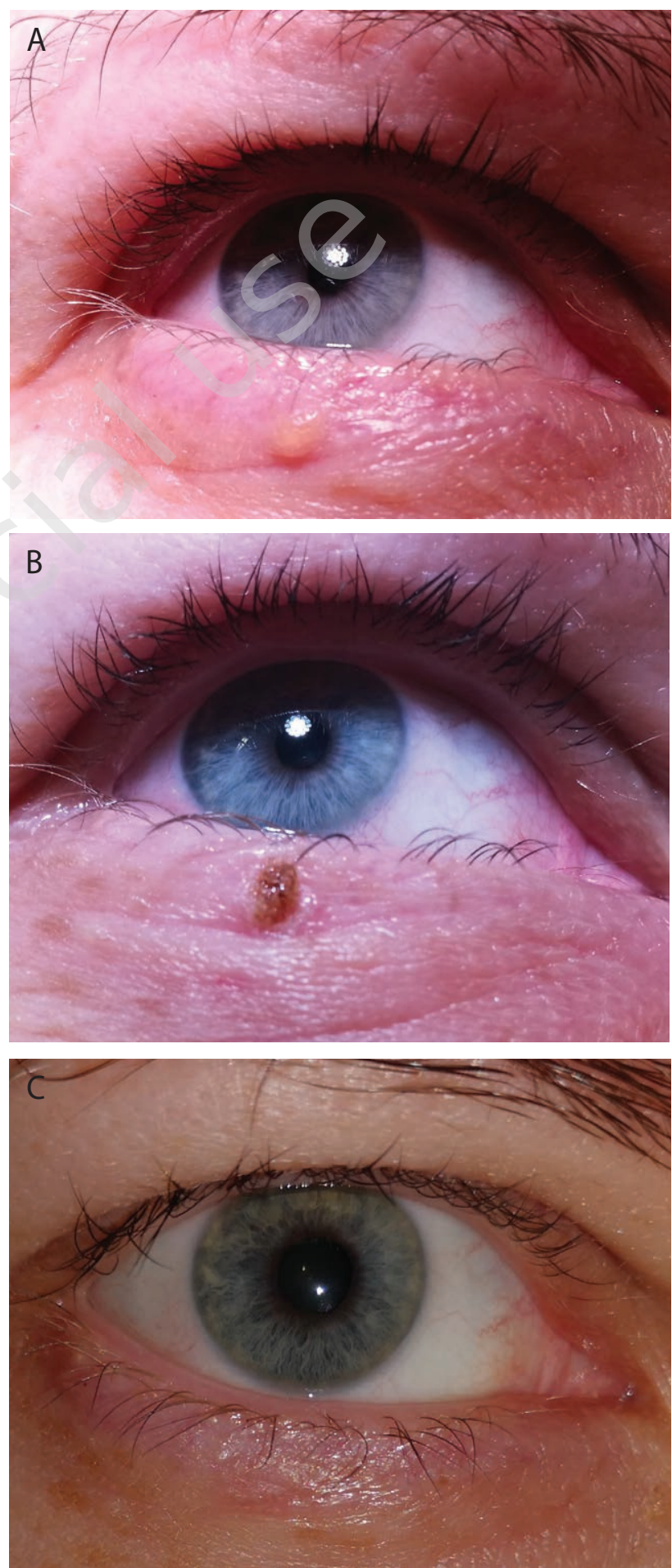


\section{RYCINA 5}

Pacjentka, I. 71. Brodawczaki powieki i brzegu powieki dolnej. A. przed zabiegiem. B. bezpośrednio po zabiegu. C. miesiąc po zabiegu.
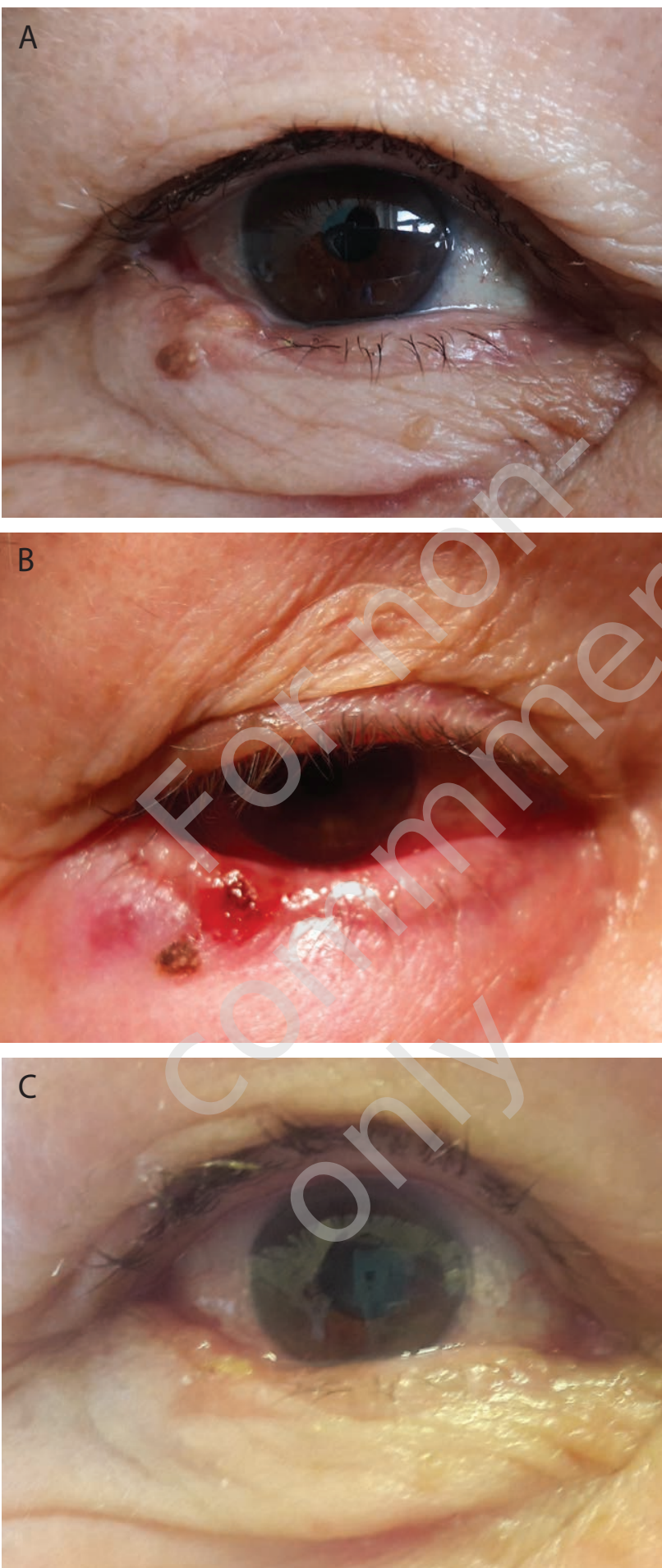

\section{RYCINA 6}

Pacjentka, I. 70. Brodawczak skóry nasady nosa.

A. przed zabiegiem. B. bezpośrednio po zabiegu. C. miesiąc po zabiegu.
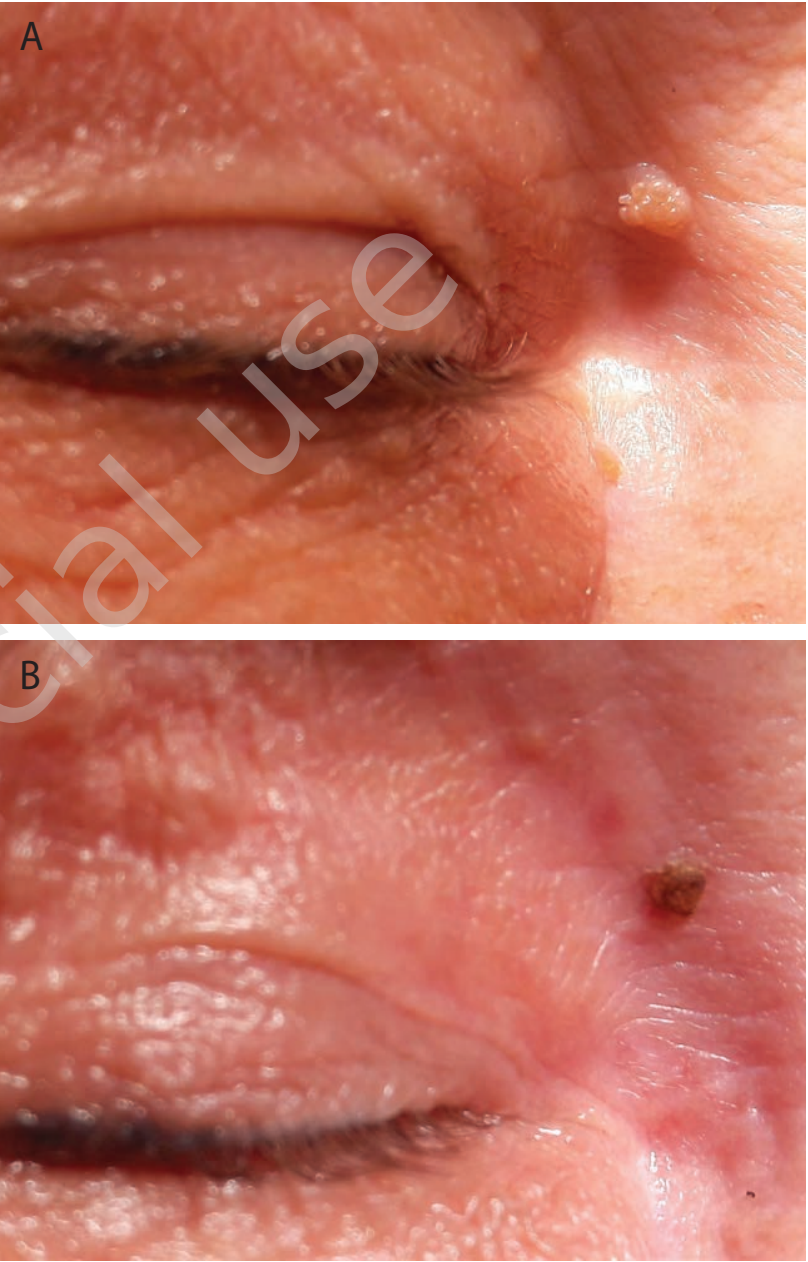

C

- Medical Education. For private and non-commercial use only. Downloaded from https://www.journalsmededu.pl/index.php/ophthatherapy/index: 26.04.2023; 08:47,03 


\section{PODSUMOWANIE}

Po wykonaniu opisanych zabiegów z zastosowaniem generatora Jett Plasma ${ }^{\oplus}$ stwierdzamy, że procedury te cechują się krótkim czasem wykonania, są bezpieczne, niebolesne i nie powodują wyłączenia pacjenta z codziennej aktywności. Miejsca po odparowaniu zmienionej tkanki szybko nabłonkują i nie pozostawiają blizn. Zabiegi te mogą być powtarzane wielokrotnie, a uzyskany efekt widoczny jest często już po kilku dniach. W przedstawionym materiale najbardziej zadowalające efekty uzyskaliśmy w leczeniu płaskich zmian umiejscowionych na brzegu powieki (m.in. włókniaki, brodawczaki). Z uwagi na to, iż generator plazmowy stosowany jest w okulistyce od niedawna, nie ma jak dotąd w dostępnej literaturze specjalistycznej istotnych publikacji na ten temat. Brakuje również randomizowanych badań klinicznych porównujących skuteczność działania aparatu w stosunku do metod chirurgicznych stosowanych w okuloplastyce. W celu określenia obszaru wskazań, w których generator Jett Plasma ${ }^{\oplus}$ pozwala osiągnać najlepsze efekty, konieczne jest wykonanie kolejnych zabiegów i obserwacja pacjentów podczas wizyt kontrolnych. Niewątpliwie zastosowanie plazmy może stanowić alternatywę dla skalpela w wybranych zabiegach okuloplastycznych.

\section{ADRES DO KORESPONDENCJ}

dr n. med. Jaromir Wasyluk

Klinika Okulistyczna,

Wojskowy Instytut Medycyny Lotniczej w Warszawie

01-755 Warszawa, ul. Krasińskiego 54/56

e-mail: jwasyluk@wiml.waw.pl

ORCID:

Jaromir Wasyluk - ID - orcid.org/0000-0002-0080-6050

\section{Piśmiennictwo}

1. Justan I, Tichý F, Slavícek P. A new type of plasma knife and its effect on biological issues - a pilot study. Acta Chir Plast 2010; 52(2-4): 31-34.

2. Fridman G, Friedman G, Gutsol A, et al. Applied plasma medicine. Plasma Process Polym 2008; 5: 503-533.

3. Heinlin J, Isbary G, Stolz W, et al. Plasma applications in medicine with a special focus on dermatology. J Eur Acad Dermatol Venereol 2011; 25(1): 1-11.

4. De Goursac C. Medical blepharoplasty using Jett Plasma Lift Medical. PRIME Int J Aesth Anti-Ageing Med 2018; 8(4): 26-31.

5. Giroux PA, Hersant B, SidAhmed-Mezi M, et al. The Outcomes Assessment of the Plasma Blade Technology in Upper Blepharoplasties: A Prospective Study on a Series of 25 Patients. Aesthetic Plast Surg 2019. DOI: 10.1007/s00266-019-01360-2. [Epub ahead of print].

6. Scarano A, Lorusso F, Brucoli M, et al. Upper Eyelid Blepharoplasty With Voltaic Arc Dermabrasion. J Craniofac Surg. 2018; 29(8): 2263-2266 . 